\title{
The Global Financial Cycle, Monetary Policies and Macroprudential Regulations in Small, Open Economies
}

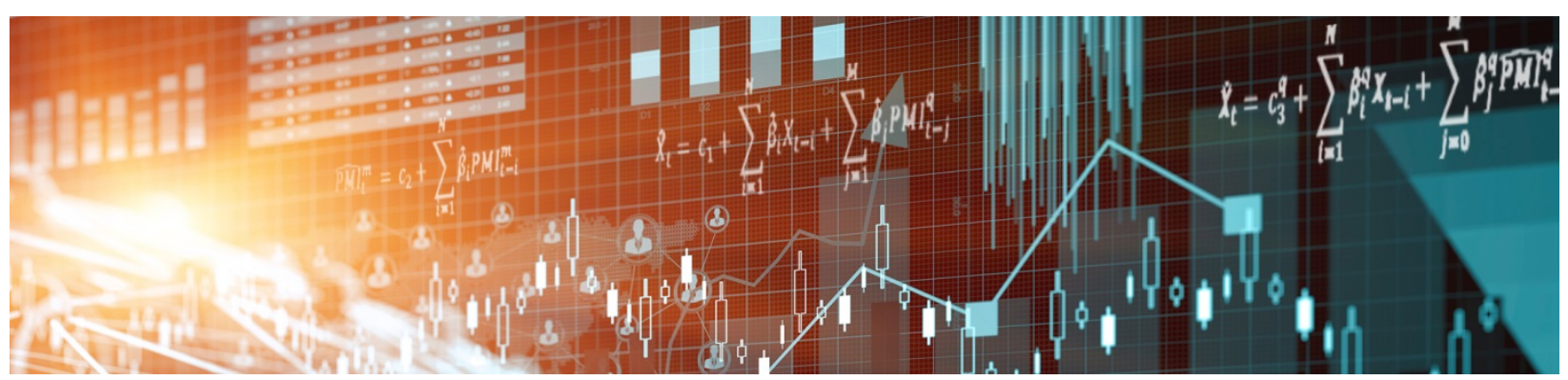

by Gregory Bauer, Gurnain Pasricha, Rodrigo Sekkel and Yaz Terajima 
Bank of Canada Staff Working Paper 2016-38

August 2016

\title{
The Global Financial Cycle, Monetary Policies and Macroprudential Regulations in Small, Open Economies
}

by

Gregory Bauer, ${ }^{1}$ Gurnain Pasricha, ${ }^{2}$ Rodrigo Sekkel ${ }^{1}$ and Yaz Terajima ${ }^{3}$

\author{
1Financial Markets Department \\ 2International Economic Analysis \\ ${ }^{3}$ Financial Stability Department \\ Bank of Canada \\ Ottawa, Ontario, Canada K1A 0G9 \\ gbauer@bankofcanada.ca \\ gpasricha@bankofcanada.ca \\ rsekkel@bankofcanada.ca \\ yterajima@bankofcanada.ca
}




\section{Acknowledgements}

We would like to thank Gino Cateau, Antonio Diez de los Rios, Jose Dorich, Michael Ehrmann, Eleonora Granziera, Sharon Kozicki, Anthony Landry, Teodora Paligorova and Alexander Ueberfeldt for helpful comments. In addition, we extend many thanks to Graeme Westwood and David Manzo for excellent research assistance. 


\begin{abstract}
This paper analyzes the implications of the global financial cycle for conventional and unconventional monetary policies and macroprudential policy in small, open economies such as Canada. The paper starts by summarizing recent work on financial cycles and their growing correlation across borders. The resulting global financial cycle may be followed by a financial crisis that is quite costly. The cycle causes time variation in global risk premia in fixed income, equity and foreign exchange markets. In turn, timevarying global risk premia affect the transmission mechanisms of both conventional and unconventional monetary policies in small, open economies. While there are large costs associated with financial crises, the paper summarizes new work showing that the central banks' leaning against the effects of the global financial cycle would typically be too costly. The paper concludes with some suggestions for the formation of macroprudential policies that are designed to offset the financial imbalances that grow during the boom phase of the cycle.

Bank topics: International financial markets; Financial stability; Housing; Monetary policy framework

JEL codes: E42, E43, E44, E52, F41
\end{abstract}

\title{
Résumé
}

Dans cet article, les auteurs analysent les implications du cycle financier mondial pour les politiques monétaires traditionnelles et non traditionnelles ainsi que pour la politique macroprudentielle de petites économies ouvertes comme celle du Canada. Ils résument d'abord de récents travaux portant sur les cycles financiers et leur corrélation croissante entre les différents pays, qui peut mener à un cycle financier mondial. Toutefois, à la fin d'un tel cycle, une crise financière assez coûteuse risque de survenir. Le cycle induit des variations dans le temps des primes de risque à l'échelle mondiale sur les marchés des titres à revenu fixe, les marchés boursiers et les marchés des changes. Ces primes ont une incidence sur les mécanismes de transmission des politiques monétaires traditionnelles et non traditionnelles dans les petites économies ouvertes. Une synthèse d'études récentes montre que, malgré les coûts considérables associés aux crises financières, il serait généralement trop onéreux pour les banques centrales de contrer les effets du cycle financier mondial. Les auteurs concluent en offrant quelques suggestions concernant la formulation de politiques macroprudentielles permettant de réduire les déséquilibres financiers qui s’amplifient durant la phase ascendante du cycle.

Sujets : Marchés financiers internationaux; Stabilité financière; Logement; Cadre de la politique monétaire

Codes JEL : E42, E43, E44, E52, F41 


\section{Non-Technical Summary}

This paper offers an overview of the implications of the global financial cycle for conventional and unconventional monetary policies and macroprudential policy in small, open economies (SOEs) such as Canada. We start by reviewing the recent evidence on financial cycles. An important new finding is that national financial cycles may have been partly subsumed into a global financial cycle. The global financial cycle is driven, in part, by monetary policy decisions in the United States. Low-for-long U.S. policy rates cause global financial intermediaries to search for yield, which in turn leads to a decline in the cross-section of international risk premia. Risk premia form an important part of conventional and unconventional monetary policy transmission mechanisms in both large and small economies.

Next, we review the available policy actions that could be undertaken by SOE central banks and regulatory authorities to limit the effects of the global financial cycle. We show that conventional monetary policy actions in both large and small economies are affected by movements in global risk premia. The paper also examines the effectiveness of unconventional monetary policies originating in SOEs that are not coordinated with those in large countries.

If unconventional policies undertaken during financial crises are not completely effective in restoring output or inflation to their target levels, the question then arises as to whether central banks can use more aggressive conventional monetary actions to lean against the buildup of debt associated with the boom phase of the global financial cycle. We highlight new work that evaluates the potential for central banks to lean against the winds of the global financial cycle. This new work shows that the cost of leaning is quite high relative to the benefits of lowering the likelihood of either entering a house price correction episode or of triggering a new financial crisis.

We then assess to what extent macroprudential policy tools could be an alternative to curb increased risk-taking behaviour during the boom phase of the cycle. In large economies, a number of macroprudential policies are designed to break the chain that links asset allocation decisions by financial intermediaries with the resultant declines in risk premia. Such policies are likely to be less effective in SOEs, as global premia will likely not change in the face of portfolio switches by small institutions or by a relatively small number of households. At the end of the paper, we use our framework to provide suggestions for macroprudential policy reforms to improve the effectiveness of the current toolkit in SOEs. 


\section{Introduction}

In the years since the global financial crisis, a deeper understanding of financial cycles and their impacts on asset prices, risk sharing and portfolio flows has emerged. There is increasing evidence of a typical boom-bust cycle: During the boom phase of a financial cycle, easier financing constraints (perhaps driven by low-for-long policy rates), decreased risk aversion, and perceptions of value self-reinforce to create higher asset prices and/or leverage. For example, financial intermediaries invest in riskier assets ("search for yield") or increase the leverage used to obtain traditional assets. As a result, risk premia fall, which induces more search-for-yield behaviour. ${ }^{2}$ Individuals may purchase homes at ever-higher levels of overvaluation (relative to long-run fundamentals). Both the demand for and supply of household and corporate debt increase. This boom phase may persist for a long time (Drehmann et al. (2012)).

Financial cycles may end in financial crises that appear suddenly. As borrowers become overextended and central banks raise policy rates, financial institutions unwind their carry trades. Risk premia increase rapidly along with the burden of the higher debt stock. Large-scale selling of financial assets and houses results in sharp price corrections. The attempt to reduce the heavy debt burden causes both growth and inflation to be low for long periods of time.

An important new finding is that national financial cycles may have been partly subsumed by a global financial cycle (e.g., Agrippino and Rey (2014), Rey (2015) and Bruno and Shin (2015)). The global financial cycle is driven, in part, by monetary policy decisions in the United States. Low-forlong U.S. policy interest rates cause global financial intermediaries to search for yield, which causes a decline in the cross-section of international risk premia. Risk premia form an important part of the monetary policy transmission mechanism in both large economies and in small, open economies (SOEs) such as Canada. ${ }^{3}$ As a result, the dynamics of debt accumulation, risk aversion, and asset prices in SOEs may now be a function of both the global financial cycle and domestic monetary policies.

Given the large costs associated with the recent financial crisis, there is a renewed interest in policy actions that could be undertaken by central banks and regulatory authorities to limit the effects of the global financial cycle. These include both conventional and unconventional monetary policies, along with new macroprudential policies. The primary focus of this literature has been on the conduct and effectiveness of these policies in large, open economies. However, understanding the SOE aspects of these policies is important for policy-makers in Canada. How do conventional and unconventional policies from large economies (primarily the United States) spill over into Canada?

\footnotetext{
${ }^{2} A$ risk premium is defined to be the additional return above that of the risk-free rate that an investor expects to earn from holding the asset.

${ }^{3}$ Examples of important risk premia in the monetary policy transmission mechanism include: the term structure risk premium, which links short-term and long-term interest rates; the credit market risk premium, which links long-term risk-free rates to their corporate counterparts that contain default risk; and the foreign exchange risk premium that leads to a failure of uncovered interest parity.
} 
How effective are Canadian versions of these polices, given the global financial cycle? How should macroprudential policies to limit the damaging effects of the global financial cycle be designed for SOEs?

This paper summarizes recent work on SOE monetary and macroprudential policies that attempt to answer these questions. This new work goes beyond the usual small-country analysis that incorporates the effects of a floating exchange rate along with an independent monetary policy. Integration with globalized financial markets implies that the conventional monetary policy actions by SOE central banks must respond to movements in U.S. policy rates and the resulting changes in global risk premia. Below, we provide an example that occurred during the boom phase of the cycle (i.e., the Greenspan "conundrum” period of 2004-06). However, the global financial cycle also has implications for unconventional policies that are undertaken during crisis periods. We also describe how the quantitative easing (QE) and other extraordinary policy actions in the United States and elsewhere spilled over into Canada. The paper also examines the effectiveness of unconventional monetary policies originating in SOEs that are not coordinated with those in large countries.

Despite the heavy use of unconventional policies, global growth and inflation both remain below desired levels. If unconventional policies undertaken during crises are not completely effective, the question then arises as to whether central banks can use more aggressive conventional monetary actions to lean against the buildup of debt associated with the boom phase of the global financial cycle. Below we highlight new work that evaluates the potential for central banks to lean against the winds of the global financial cycle. This new work shows that the cost of leaning (by keeping rates higher than warranted by current economic conditions) is quite high relative to the benefits of lowering the likelihood of either entering a house price correction episode or triggering a new financial crisis.

If leaning is too costly to counter the global financial cycle, policy-makers could decide to turn to macroprudential policy tools to curb increased risk-taking behaviour. In large economies, a number of macroprudential policies are designed to break the chain that links asset allocation decisions by financial intermediaries with the resultant declines in risk premia. Such policies are likely to be less effective in SOEs, as the global risk premia will likely not change in the face of portfolio switches by small institutions or by a relatively small number of households. At the end of the paper, we use our framework to provide suggestions for macroprudential policy reforms to improve the effectiveness of the current toolkit in SOEs. ${ }^{4}$ We also present a brief analysis of an important topic that has long been neglected in the developed-country policy arsenal: capital controls.

The new global financial cycle literature has important implications for the independence of monetary policy in SOEs. For example, Rey (2015) suggests that the influence of the global financial cycle is so pervasive that most SOEs have lost the ability to conduct an independent monetary

\footnotetext{
${ }^{4}$ Canada has implemented a number of macroprudential policy reforms. See Damar and Molico (2016) for a review.
} 
policy, absent capital controls (i.e., the classic Mundellian trilemma has become a dilemma). The preliminary evidence on this topic is reviewed below. However, we do not believe that the global financial cycle has negated domestic policies; rather, we simply suggest that the global financial cycle has important implications for the conduct of monetary and macroprudential policies in SOEs.

In addition, this literature does not suggest that monetary policy actions by SOE central banks are ineffective. For example, Choudhri and Schembri (2013) examine the experience of Canada and the United States during the run-up to the two biggest financial crises in global history-in the 1920s and 2000s — and the roles of their monetary and financial stability policies. They present evidence to suggest that more moderate monetary policy in Canada did limit the extent of economic expansion in Canada in the pre-2008 period. These experiences and the recent work suggest that a mixture of policies is likely required. For example, during the boom phase of the financial cycle, domestic conventional monetary policy actions may have to be larger to offset decreasing global term premia. Macroprudential policies can also be used, but may require an enhanced level of coordination between domestic regulators and across countries to limit the effects of global risktaking behaviour.

In what follows, Section 2 surveys some of the evidence on the global financial cycle. It also explains some recent work on risk assessment models. Section 3 shows how time variation in global risk premia affects the transmission of conventional and unconventional policy actions in SOEs. Section 4 summarizes new work that estimates the effectiveness of conventional monetary policy actions to lean against growing financial imbalances in the boom phase of the cycle. Section 5 discusses the implications of this framework for macroprudential policies. Finally, Section 6 concludes.

\section{The global financial cycle and crises}

Since the onset of the global financial crisis of 2007-09, there has been a large amount of work devoted to understanding the causes of financial cycles and their importance for growth and inflation. We start by outlining the nature of global financial cycles before turning to the determinants of financial crises. We then summarize recent work on assessing the level of risk, including the early warning indicator model of Pasricha et al. (2013), and the Bauer (2014) model of house price corrections.

\section{Global financial cycles}

A number of recent studies have applied traditional business cycle dating methods to identify financial cycles. The result is a set of identified financial booms and three key stylized facts that are 
robust to the different methodologies. ${ }^{5}$ First, fluctuations in credit and property prices offer a parsimonious description of the financial cycle. Much of the recent literature thus focuses solely on credit quantities to characterize the financial cycle. Second, financial cycles have a much lower frequency than business cycles. Whereas business cycles involve fluctuations of around one to eight years, the average financial cycle tends to last twice as long. Finally, financial cycle peaks may be followed by financial crises. While credit booms are found to be a significant predictor of financial crises, and hence, sharp drops in economic activity, not all credit booms end in a crisis. However, Mian and Sufi (2015) show that an increase in the debt-to-GDP ratio forecasts future lower GDP growth. Thus, even if there is no crisis per se, the buildup of credit in the economy has negative consequences, as also highlighted by Dell'Ariccia et al. (2012).

The causes of financial cycles are uncertain. Financial innovation may lead to an increased degree of financial deepening, which relaxes the constraints faced by firms and households. There may be a decrease in risk aversion that comes from time-varying risk-based capital constraints (e.g., Adrian, Moench and Shin (2014)). A number of behavioural explanations have been proffered (e.g., Barberis (2013) suggests that expectations may be extrapolative; Reinhart and Rogoff (2009) argue that agents view their particular circumstances as being different from past ones; Baron and Xiong (2014) argue that agents appear to ignore the increasing likelihood of a financial crisis as the amount of credit in the economy increases). Agency problems within financial institutions may also be blamed (e.g., Allen and Gale (2000)). Central banks may maintain “low-for-long” policy rates that encourage additional risk-taking (e.g., Borio and Zhu (2008), Bruno and Shin (2015), Paligorova and Santos (2012), Paligorova and Sierra (2012) and Jiménez et al. (2012, 2014)). Of course, some combination of all of these factors may be present.

More recently, several authors have observed that, since the 1990s, financial cycles have become more global in nature. Rey (2014), Agrippino and Rey (2014), and Passari and Rey (2015) have shown that global factors explain an important share of movements in a large cross-section of asset prices, balance sheets of financial intermediaries, and in cross-border capital flows. The U.S. monetary policy stance is the main driver of the global financial cycle because of the international role of the dollar as a funding and investment currency. Changes in U.S. policy rates affect the net worth of global investors and financial intermediaries. In large vector autoregression (VAR) models estimated using Bayesian techniques, Agrippino and Rey (2014) and Passari and Rey (2015) show that the shocks to the U.S. policy rate have a significant impact on the VIX (the implied volatility of the S\&P 500 stock index that is used as a proxy for risk aversion), capital flows, leverage of global banks, and global asset prices.

The central role of U.S. monetary policy in driving risk aversion and financial spillovers is reinforced in other studies. Bekaert et al. (2013) decompose the VIX into a risk aversion and an uncertainty component. They study how lax monetary policy increases future risk appetite (i.e., decreases risk

\footnotetext{
${ }^{5}$ See, for example, Jordà, Schularick and Taylor (2011), Dell'Ariccia et al. (2012), Claessens, Kose and Terrones (2012), Borio (2014), and Drehmann, Borio and Tsatsaronis (2011), among others.
} 
aversion) in the United States. The effects are persistent, lasting for more than two years. Gertler and Karadi (2015) combine a traditional monetary VAR with high frequency identification of monetary policy shocks. They show that term premia and risk spreads react strongly to monetary policy shocks. They argue that this is an important channel through which monetary policy affects the economy. Hanson and Stein (2015), as well as Rogers, Scotti and Wright (2015) also show that conventional and unconventional monetary policy has an impact on risk premia in bond and other financial markets.

One question of interest is how much a floating exchange rate can insulate an SOE from the global financial cycle. This literature is contentious and no clear conclusion has been reached. On the one hand, Rey (2015) argues that the effects of the global financial cycle are so pervasive that it has largely negated the traditional monetary trilemma (i.e., countries must choose between any two of monetary policy autonomy, exchange rate stability, and financial openness). Instead, she argues, countries now face a dilemma: If the country wishes to have monetary policy autonomy, then it must sacrifice financial openness. In her empirical analysis, Rey shows that capital flows and international bank leverage both react to a U.S. monetary policy shock. Of interest, a U.S. monetary

policy tightening causes mortgage spreads in Canada (and in other countries) to widen. Bruno and Shin (2015) use a structural VAR to show that a positive U.S. monetary policy shock leads to a decline in both U.S. cross-border capital flows and in international bank leverage, resulting in an appreciation of the U.S. dollar.

On the other hand, some papers argue that the trilemma framework for monetary policy remains intact. Aizenman et al. (2015) use data from a large set of developed and developing countries in a two-step analysis. In the first step, they estimate the sensitivity of their financial variables to the core economies. In the second step, they relate the sensitivities to a large number of country characteristics. They find that the choice exchange rate regime does affect the extent to which peripheral countries are affected by policy choices of the United States. Similarly, Klein and Shambaugh (2015) estimate interest rate parity equations with panel methods to show that a floating exchange rate allows monetary policy autonomy in the presence of capital mobility. One may thus argue that the emergence of global financial cycles may have reduced the monetary policy autonomy of a floating exchange rate regime, but that it does not imply that the choice of exchange rate regime is irrelevant.

\section{Crises}

Financial cycles may end in financial crises. An understanding of the dynamics of the former helps explain the occurrence of the latter. Most of the recent academic work on crisis prediction stems from Schularick and Taylor (2012), who investigate the causes of financial crises using a long historical (starting in 1870) data set of 17 advanced economies, including Canada. Financial crises 
are relatively infrequent events, accounting for only 28 per cent of the recessions experienced by the 17 economies since $1870 .{ }^{6}$ Further, the fraction of recessions associated with financial crises declined in the post-WW2 period: a fourth (23 out of 88 recessions) in the post-WW2 era were classified as financial crisis recessions, compared with nearly a third of all recessions in the preWW2 era (23 out of 78 recessions).

While financial crises became less common in the post-WW2 period, they were more costly. The cumulative output gap between normal and financial recessions, measured 5 years from the start of the recession, amounted to 22 per cent of real GDP per capita in the post-WW2 period, compared with about 16 per cent in the pre-WW2 period (Jordà, Schularick and Taylor (2015)). Reinhart and Rogoff (2014) construct a sample of 100 systemic banking crises in advanced and major emerging economies over the period 1857-2013. They find that the median time for countries to reach pre-crisis levels of per-capita real income was 6.5 years. However, the recovery time in the post-WW2 period was longer-about 8 years-suggesting a long-run, significant output gap. In fact, Cerra and Saxena (2008) find that in the post-WW2 period, on average, output losses (relative to pre-crisis trend) from financial crisis in advanced economies were not recovered even after 10 years.

Given the high costs of financial crises, it is important to understand which factors can help predict the incidence and severity of a crisis. The main conclusion of the recent literature is that the rapid expansion of credit is one of the better predictors of crises. ${ }^{7}$ For example, Schularick and Taylor (2012) find that a one-standard-deviation-higher real bank loan growth over the previous five years increases the probability of a crisis in the current year by 2.1 to 2.8 percentage points. ${ }^{8}$ In subsequent work, Jordà, Schularick and Taylor (2014) show that it is the growth of mortgage credit that is the most risky form of credit for future crises. ${ }^{9}$

While recessions driven by financial crises are more severe than normal recessions, there is a lot of variation around this average. Not every financial crisis is equally severe, and a large literature has tried to determine what makes one crisis more severe than another. It turns out that leveraged

\footnotetext{
${ }^{6}$ That is, 46 out of 166 recessions experienced by these economies between 1870 and 2010 were associated with a financial crisis.

${ }^{7}$ However, credit booms are not a perfect predictor in that not all booms end in financial crises or recessions. Similarly, not all asset price bubbles end in recessions or crises. Schularick and Taylor (2012) conducted robustness checks using a host of other factors including inflation, real GDP growth, interest rates, narrow and broad money, and the ratio of loans to GDP (rather than their growth rate). Of all the factors they examined, loans to GDP provided the most predictive power over and above that provided by lagged loan growth, while most other factors, notably interest rates, did not provide any additional predictive ability.

${ }^{8}$ This compares to the 4 per cent probability of crisis per year since 1971, in their sample of 14 advanced economies.

${ }^{9}$ Adding asset price bubbles to the model improves the predictive ability of a financial recession over credit bubbles alone-but not by a lot. However, the coefficients of the interaction terms between asset prices and credit bubbles are significant, especially for housing bubbles and both bubbles (housing and equity).
} 
asset price bubbles not only increase the probability of a crisis, but they also increase its severityespecially when the asset in question is housing (Chart 1). Recessions associated with the busting of equity bubbles (shown on left of Chart 1 ) were not much more severe than normal recessions (especially in the post-WW2 period). However, when the equity bubble was associated with aboveaverage growth in credit, the subsequent recession was more severe than a normal recession. In contrast, bubbles in housing prices are associated with noticeably worse recession and recovery paths (shown on right of Chart 1). Moreover, the downturn is deeper when the housing bubble is accompanied by a credit boom. On average, after a credit-fueled house price bubble, advanced economies had not recovered from the recession even after five years from the start of the recession. ${ }^{10}$

While credit booms and leveraged asset bubbles are good leading indicators of crisis incidence and severity, financial conditions at the start of the crisis can also predict the severity of the subsequent macroeconomic losses. A sharper increase in credit spreads at the start of the financial crisis forebodes a deeper GDP contraction and a slower recovery (Krishnamurthy and Muir, 2015).

Given the large potential costs of financial crises, there is a renewed interest in predicting their occurrence. There are two main types of predictive methods. The first is labelled early warning indicator (EWI) models, an example of which is Pasricha et al. (2013). This model assesses the vulnerabilities in the economy by estimating whether specific indicators are above threshold levels that were breached prior to previous financial stress episodes. Historical stress episodes are identified using two methods: (1) the financial stress index developed by the International Monetary Fund (IMF) for 17 advanced economies; and (2) a narrative approach from the existing literature for identifying banking crises. A total of 37 episodes of financial stress across all of the countries were observed. Current readings of economic and financial indicators are compared with their estimated thresholds, and indicators that are higher than their thresholds are aggregated into a per cent measure, as in Christensen and Li (2014). ${ }^{11}$

The second type of model directly assesses the likelihood of a future event based on a probability model estimated using past events. Schularick and Taylor (2012) are an example of this type of model applied to predicting financial crises. Bauer (2014) uses this approach to estimate the likelihood of a large house price correction (when the real national house price index falls by at least 10 per cent and the decline lasts at least one year) over the next two years. The model uses an estimate of the degree of overvaluation of house prices at the national level as a forecasting

\footnotetext{
${ }^{10}$ Other papers that focus on the roles of house price booms as a harbinger of financial instability include Büyükkarabacak and Valev (2010), Demirgüç-Kunt and Detragiache (1997), and Alpanda and Ueberfeldt (2016).

${ }^{11}$ There are 16 core indicators for the model, including different measures of household and non-household leverage; monetary bases (M3 and M1); household debt, income and housing prices; financial indicators, including financial sector debt, equity prices, and returns equity indexes; and external factors relating to current account deficit. The composite indicator weights the individual indicators by their signal-to-noise ratios.
} 
variable. ${ }^{12}$ The estimated overvaluation is combined with the two components of the long-term interest rates (the decomposition is described in Section 3 below) and the estimated growth of real credit to forecast the likelihood of a large house price correction. Similar to the previous model, the scarcity of national house price corrections in any one country mandates the use of a cross-country panel framework. The results show that the selected variables can forecast house price corrections on a historical basis.

While both types of models may potentially help guide policy actions, they do not offer certainty regarding future crisis events. For example, no model implies that the likelihood of a future financial crisis is 100 per cent and, conversely, false positives are always present. This by itself suggests that using monetary policy to lean against the rise of debt would be risky (see Section 4 below). For example, in the Jordà, Schularick and Taylor (2015) data set, not all bubbles end in recessions or crises; there are 29 equity price bubbles and 9 housing bubbles in their full sample that simply blow over. Predicting rare events and their consequences is difficult.

\section{Conventional and unconventional monetary policies in SOEs with globally integrated markets}

To understand how the global financial cycle affects the conduct of monetary policy in SOEs, it is necessary to understand the important role of time-varying risk premia in the monetary policy transmission mechanism. We thus start with an analysis of the term structure risk premium from Bauer and Diez de los Rios (2012). The lesson from this work is that time variation in global risk premia has implications for the conduct of conventional monetary policies in both large and small economies. We then show how a large increase in the risk premium will affect the effectiveness of unconventional monetary policies during financial crises.

\section{Conventional monetary policy}

Long-term government bond yields can be decomposed into two parts: (1) an expectations component that captures the market's view of current and future short-term policy rates; and (2) a term structure risk premium that is the extra compensation that investors require for holding a long-term bond. Bauer and Diez de los Rios (2012) show that term premium fluctuations are determined globally as investors allocate portfolios across international bond markets. As a result, country-specific (i.e., idiosyncratic) risk is largely diversified away. The remaining systematic risks

\footnotetext{
${ }^{12}$ The house price model is in the form of a present value relationship based on treating a house as an asset. The price of the house is the expected discounted value of future cash flows from the home (proxied by national per capita real disposable income), discounted using a rate that accounts for the duration and riskiness of the cash flows (proxied by long-term government bond yields).
} 
are captured by the term structure risk premium that responds to worldwide factors such as growth in the global economy. ${ }^{13}$

Chart 2 shows the expectations component of long-term government bond yields in both Canada and the United States since 1975 from the Bauer and Diez de los Rios (2012) model. The grey segments of the graph indicate a recession period in the United States, according to the National Bureau of Economic Research. The graph shows that interest rates have declined from the very high levels reached during the early 1980s. At that time, the U.S. Federal Reserve raised short-term interest rates in an attempt to reduce the high level of inflation. Following the dramatic reduction in inflation, long-term rates have slowly declined.

The model also shows a great deal of variation in the second component of the decomposition, term structure risk premia (Chart 3). Term premia are countercyclical, rising sharply in recessionary periods as investors become more risk-averse. ${ }^{14}$ In contrast, term premia decline during expansionary periods. For example, they were declining from the early 1990s to the early 2000s, reflecting the reduction of the level of global inflation and the Great Moderation.

The importance of global risk premia for the monetary policy transmission mechanism was illustrated during the 2004-06 period. Chart 4 shows that between August 2004 and June 2006, the Bank of Canada increased the overnight rate by 225 basis points (bps). Over the same period, the 10-year rate on Canadian government bonds decreased by about 30 bps. Similarly, from May 2004 to June 2005, the Federal Reserve increased the U.S. short rate from 1.64 per cent to 3.86 per cent. However, long-term interest rates fell, with the 10-year rate declining from 4.74 per cent to 4.33 per cent. Thus, while central banks were attempting to tighten monetary policy, the cost of longterm, risk-free credit was declining. As this phenomenon was a surprise to the Federal Reserve, former Federal Reserve Chairman Greenspan labelled this behaviour as a "conundrum," as the then-existing models of the U.S. term structure had trouble explaining the events.

Bauer and Diez de los Rios (2012) show that this is a "conundra," as the same event occurred across a range of global bond markets. Chart 2 shows that during this period, the expectation components of the 10-year Canadian and U.S. long-term yields were increasing, indicating that market participants were (correctly) increasing their expectations of the future paths of the shortterm policy rates. However, the risk premium components of the yields in the two countries fell

${ }^{13}$ Global factors are shown to be present in the expected excess returns of developed-country bond markets by Driessen, Melenberg and Nijman (2003), Perignon, Smith and Villa (2007), Bekaert and Wang (2010), Hellerstein (2011), Dahlquist and Hasseltoft (2013) , and Bauer and Diez de los Rios (2012) and in emerging-market bonds by Longstaff et al. (2011). Global risk premia in equity markets are shown by Campbell and Hamao (1992), Harvey, Solnik and Zhou (2002), Bekaert and Wang (2010), Lewis (2011) and Rangvid, Schmeling and Schrimpf (2014).

${ }^{14}$ In addition to Bauer and Diez de los Rios (2012), several other papers have highlighted the countercyclical movements in term premium including Fama and Bliss (1987), Campbell (1987), Campbell and Shiller (1991), and Cochrane and Piazzesi (2005). 
during this time, as the global economy was expanding and investors were becoming less riskaverse (Chart 3). Thus, changes in global risk premia were diminishing the effectiveness of central bank conventional monetary policies.

\section{Unconventional policies at the end of financial cycles}

Central banks also need to account for time variation in global risk premia during recessions or financial crises. The large swings in the premium during the Great Recession provide a powerful example. The expectations component declined sharply at the onset of the recession, reflecting the market's expectation of additional monetary policy easing (Chart 2). However, the rise in term structure risk premia during the same period was unusually short-lived, as shown in Chart 3 . While risk premia rose sharply at the end of 2008, by early 2011 they had returned to the pre-crisis levels. $^{15}$

The most likely cause of the recent quick decline in term structure risk premia is the use of unconventional monetary policies in the United States, including direct purchases of long-term Treasury bonds as part of quantitative easing policies. There is now a large literature examining the impact of unconventional policies on bond yields. Using an event-study methodology, Gagnon et al. (2011), Krishnamurthy and Vissing-Jorgensen (2011), D’Amico and King (2013) and others find that the U.S. QE program has been successful at lowering treasury yields, as well as other corporate and mortgage bonds in the United States. ${ }^{16}$ Christensen and Rudebusch (2012) use a term structure model to show that the U.K. QE program had a significant impact on long-term rates, mainly through the risk premium channel. Kapetanios et al. (2012) use different structural VARs to study the economy-wide effects of QE in the United Kingdom. They find that QE raised the level of U.K. real GDP by 1.5 per cent, and of consumer prices by 1.25 per cent, though these estimates are subject to large uncertainty. Thus, QE programs appear to be effective in large economies. Significant asset purchases by central banks in these countries can be effective in reducing the term structure risk premium.

The recent literature has also examined the spillover effects of the U.S. unconventional monetary policies on smaller countries. For example, Dahlhaus, Hess and Reza (2014) use a factor-augmented VAR (FAVAR) model to assess the impact of U.S. QE on Canada and find that Canadian interest rates and asset prices move in the same direction as those in the United States following the implementation of U.S. QE. Along with the effects of improved terms of trade, spillovers from the financial channel bolster the domestic Canadian economy, driving up Canadian demand for imports, while the appreciation of the Canadian dollar makes imports cheaper. As a consequence,

\footnotetext{
${ }^{15}$ In contrast, during the 2001 U.S. recession, the risk premium on Canadian government bonds experienced a significant spike, and it took roughly four years before it returned to its original levels. Even longer risk premium cycles were observed after the 1983 and 1991 recessions.

${ }^{16}$ For a brief summary on the evidence of QE effects, see Reza, Santor and Suchanek (2015).
} 
net exports fall, despite the fact that Canadian exports increase in most product categories, consistent with a stronger U.S. economy. ${ }^{17}$

However, apart from the studies on the United Kingdom, the evidence on the effectiveness of QE programs launched by central banks in SOEs does not appear to exist. We note that while QE programs in SOEs may not change the global risk premium, they could work through other channels such as the exchange rate. In addition, there are other unconventional policies that can be implemented. Poloz (2015) notes that forward guidance, credit easing and negative policy interest rates are all part of an updated central bank toolkit. Indeed, the use of unconventional policies in both large and small economies may be more frequent. For example, if the Federal Reserve believed that the zero lower bound on the policy rate was to be respected, then it would have been difficult to fight the effects of the sharply increasing term premium on long-term interest rates without using unconventional policies. ${ }^{18}$ This situation is likely to persist in a world where the (global) neutral policy rate is reduced because of a number of long-run structural forces (Mendes (2014)).

We note that the effects of time variation in risk premia are also evident in credit markets. For example, Gilchrist and Zakrajsek (2012) show that U.S. corporate bond risk premia are countercyclical. The same phenomenon may hold in Canada as well. In Chart 5, the long-term (average) effective rate to businesses (i.e., a weighted average of corporate bond rates of different maturities) is shown along with the average yield on a basket of government bonds chosen to match the maturity of the corporate bonds. The Bank of Canada lowered rates aggressively after October 2008 in response to the turmoil in financial markets, as well as expected low inflation. Long-term government bond yields declined as a result of both the easing of domestic monetary policy and the U.S. QE policies. However, long-maturity corporate bond rates increased by more than 200 bps during the same period, with the rates remaining higher for almost one year. This likely reflects an increase in the Canadian corporate bond risk premium, which more than offsets the decrease that results from the change in the policy rate.

To summarize, recent work has shown that prices of risk (risk premia) are key variables in the monetary policy transmission mechanism. In globally integrated markets, the prices of risks are determined by global forces and behave countercyclically. When this phenomenon is combined with the lower level of neutral policy interest rates, conventional monetary policy moves may have to be larger to offset countercyclical risk premia. Crisis episodes may require the implementation of non-conventional policies, as risk premia increase quickly in downturns. Together, these phenomena suggest potentially greater use of unconventional policies in stressful times.

\footnotetext{
${ }^{17}$ See also Neely, C. J. (2015) and Rogers, Scotti, and Wright (2015).

${ }^{18}$ For a discussion of the evolution of unconventional monetary policies, see Poloz (2015).
} 


\section{Monetary policy and financial imbalances}

The boom phase of the global financial cycle is associated with increases in debt and asset prices that may lead to financial crises. The question then arises as to whether central banks can lean against growing financial imbalances to reduce the likelihood of a subsequent crisis. The optimal decision of whether to lean against credit imbalances or to clean up after the resulting crisis can be assessed using a number of factors (Svensson (2014, 2015)). The expected cost of experiencing a financial crisis can be estimated from the increase in private sector debt, the subsequent likelihood of entering a financial crisis, and the resulting costs in unemployment including, perhaps, a permanent loss of potential output. These costs must be weighed against those associated with higher policy rates that lean against increasing credit in boom times.

We are now in a position to use our enhanced global financial cycle framework to evaluate the leaning versus cleaning decision while accounting for the effect of monetary policy on debt dynamics. Two new papers show the links. The first, Bauer and Granziera (2016), estimates the impact of a monetary policy shock on long-run measures of stability, including the likelihood of a financial crisis (which is a function of the debt-to-GDP ratio). The authors implement a two-part model. In the first part, they estimate 18 OECD country VARs where each country VAR includes the debt-to-GDP ratio, the growth of real output, the inflation rate, the real house price index, and the short-term interest rate. A (structural) monetary policy shock is identified through sign restrictions as a 100 basis-point increase in the short rate accompanied by contemporaneous declines in real growth, inflation and real house prices. The impulse response functions are then aggregated across all of the countries using the precision of the individual country estimates as weights.

Chart 6 shows the aggregate impulse response functions from the monetary policy shock. The shock to the current level of the short-term interest rate is persistent. Both real growth and inflation decline in the short run (by construction) but the declines persist as the interest rate remains high. In line with the findings of Bauer (2014), house prices fall sharply and the growth rate remains negative through the forecast horizon. The increase in interest rates pushes the debt-toGDP ratio up in the short run, as short-term loans are more expensive to roll over. Over the long run, the stock of private debt declines, so the debt-to-GDP ratio declines as well.

In the second part of the model, the likelihood of a financial crisis starting sometime in the next two years in each of the countries is estimated using a panel logit model. Following the existing literature, the likelihood is a function of the debt-to-GDP ratio in each country. The probabilities are calculated for three different levels of the initial debt-to-GDP ratio: the ratio is at trend, or the ratio is 5 or 10 per cent above trend. This allows the authors to assess whether it would be better for the central banks to intervene early in the financial cycle (when imbalances are low) as compared to later, once imbalances are much higher.

Chart 7 shows the results. If the debt-to-GDP ratio is at trend (black line at bottom of chart), the initial probability of a financial crisis starting sometime in the next two years is approximately 7 per cent. However, the monetary policy shock causes an increase in the debt-to-GDP ratio, which 
increases the likelihood of a crisis. If the ratio starts at 10 per cent above its trend (red line at top of chart), the initial probability is about 20 per cent per annum. This also rises, reaching a level of approximately 32 per cent after 1.5 years. The monetary policy shock thus significantly increases the risk of a financial crisis in the short run. It takes a long time for the estimated likelihoods to return to their initial levels (approximately 3.5 years). It is only over quite a long forecast horizon that the amount of risk is substantially reduced.

While the Bauer and Granziera (2016) result would indicate that leaning would be effective only in the long run, the model is not able to provide a utility-based evaluation of the costs and benefits. The second model, Alpanda and Ueberfeldt (2016), is able to do this. The model endogenizes the Bauer (2014) methodology to calculate the likelihood of a large house price correction. The likelihood of a correction is a function of the deviation of the level of real credit from its trend level. For Canada over the recent decade, the credit deviation has followed the degree of house price overvaluation, both in size and direction. When a correction starts, the economy changes regime and enters a recessionary period. Those recessionary periods are severe, with a cumulative aggregate consumption loss of 14 per cent over 10 quarters. ${ }^{19}$

In the model, the risk premium on household borrowing rates is countercyclical, rising sharply in the crisis regime, which increases the cost of borrowing. ${ }^{20}$ The central bank policy rate may hit the zero lower bound, resulting in an increase in inflation and output volatility during recessionary episodes.

The authors use this framework to evaluate the effectiveness of two alterative monetary policy regimes. In the first, the central bank follows a standard Taylor rule, while in the second, the bank follows an expanded Taylor rule that responds to the upside deviation of real credit from trend. The authors are then able to evaluate the trade-off between the two rules.

When the central bank chooses to follow a standard Taylor rule, the distribution of the borrowers' debt over time allows for high levels of debt that increase the likelihood of crisis periods. On the other hand, when the bank follows the modified Taylor rule, the higher levels of the debt become less likely and the economy slips into a crisis period far less frequently.

Thus, leaning is successful in reducing the tail risks inherent in the debt cycle dynamics. However, this marginal benefit comes at a high marginal cost, as the average consumption of the borrowers is lower. Aggregate welfare in the economy is thus lower with leaning. In essence, leaning is using a first-order penalty to solve a second-order problem. The insurance cost to reducing the likelihood of a tail event is simply too high in this model, suggesting that central banks on their own should clean and not lean.

\footnotetext{
${ }^{19}$ Note that this is roughly equivalent to the consumption loss experience in the United States following the Great Depression. Qualitatively, the results stay the same, even for a much larger cumulative loss of 26 per cent over 10 quarters, as is shown in an alternative scenario.

${ }^{20}$ This aspect of the model is in line with the findings of the previous section.
} 


\section{Implications for macroprudential policies}

If central banks should not lean to reduce financial imbalances, they may decide to turn to macroprudential measures to offset the boom phase of the financial cycle. In this section, we use our framework to understand the role of macroprudential policies in SOEs. As macroprudential policies are designed to overcome particular financial frictions (Bean et al., 2010), we first provide a reinterpretation of the risk-taking channel in SOEs where risk premia are determined in global markets. We then turn to the implications for the optimal design of macroprudential policies. ${ }^{21}$

\section{Reinterpreting the risk-taking channel}

Changes in monetary policy interest rates operate on the economy via a number of channels. Recent research has highlighted the "risk-taking channel" as an important component of the financial cycle (e.g., Borio and Zhu (2008), Adrian, Estrella and Shin (2010), Adrian, Moench and Shin (2010), Adrian, Colla and Shin (2012), Paligorova and Sierra (2012), Paligorova and Santos (2012), Damar, Meh and Terajima (2013, 2015), Alpanda, Cateau and Meh (2014) and Shin (2015)). This channel focuses on changes to the asset and liability management decisions of financial institutions arising from low risk-free rates.

Borio and Zhu (2008) point out three ways that low-for-long policy interest rates can influence investor asset and liability allocations. The first is that lower policy rates will affect the first moments of risky asset returns by increasing expected cash flows and incomes. The value of collateral in securitized lending will thus rise. As a result, the perceived riskiness of financial assets decreases and investors will be more willing to allocate funds to riskier assets.

The second way that low-for-long interest rates may affect risk premia is by increasing the predictability of monetary policy. In the analysis presented above, the conquest of global inflation has reduced the necessity of having high yields and may have reduced the term structure risk premium. With apparently reduced volatility, value-at-risk constraints would be relaxed with a resultant greater willingness to take on more risk. ${ }^{22}$

\footnotetext{
${ }^{21}$ The main objective of macroprudential policies is to prevent and mitigate the buildup of systemic risk in financial systems. Excessive risk-taking due to low-for-long monetary policy rates can contribute to such buildup. Although this paper focuses on this particular channel, it is only one type of market failure that potentially leads to the buildup of systemic risk with negative externality on the economy. We can broadly categorize such market failures into three groups: incentive problems, information frictions and coordination problems. Excessive risk-taking due to low-for-long monetary policy rates would mostly fall under the information frictions category, where "search for yield" can be driven by investors' false expectations that the policy rate would stay low indefinitely. See Saporta (2009) for these discussions.

${ }^{22}$ Monetary policy may also be perceived as reducing the likelihood of tail events ("Greenspan put"). If there was a crisis, monetary policy would be able to clean up so well that income would hardly waver. However, it
} 
The third mechanism - the subsequent search for yield-is a consequence of the first two. As policy interest rates fall and are kept low, financial intermediaries must try to increase profitability by either: (a) investing in assets with higher expected excess returns (and thus load higher on systematic risks); or (b) increasing leverage. Increased purchases of assets further drive down systematic risk premia. The decline in expected excess returns in turn leads to a continuing search for yield across the lower credit rating portion of the spectrum of risky assets. Risk premia on these assets subsequently fall. When the monetary easing ends, intermediaries take advantage of higher yields on conventional assets and unwind their carry trades. The resulting negative shocks to asset prices then cause large swings in financial intermediaries' leverage, with further negative feedback loops to asset prices and the real economy.

The global financial cycle framework presented above changes the way that we view the risk-taking channel. Movements in U.S. policy rates cause changes in global risk aversion and in the asset and liability decisions of global financial intermediaries. These global forces cause changes in risk premia in all countries that are integrated with global markets. This implies that the risk-taking channel will be driven by global portfolio allocations. The financial intermediaries that are reallocating their assets and liabilities over the financial cycle must be large enough to affect global prices. Financial intermediaries in SOEs are unlikely to have a significant influence on global prices. $^{23}$

\section{Macroprudential regulation}

Macroprudential policies have been suggested for dealing with the negative effects of the financial cycle (e.g., BIS (2012); BIS, FSB and IMF (2011)). "Macroprudential" denotes any measure that aims to address two key concerns: (1) the procyclicality of finance, i.e., the existence of mechanisms through which the financial system can amplify the business cycle; and (2) the stability of the financial sector as a whole, rather than individual institutions. ${ }^{24}$ Policies may be in the form of either "through the cycle" tools that aim to build structural resilience of the financial system against systemic shocks, or countercyclical tools that are designed to limit the increase in systemic risk by "leaning against the wind". ${ }^{25}$ The focus here is on the implications of the global financial

is difficult to know how this put option would be priced today, given the length and depth of the Great Recession.

${ }^{23}$ The global top 10 financial intermediaries had approximately USD 21 trillion under management in 2013 (P\&I Towers Watson (2014)). For Canada in 2013, the top 10 firms (that range in global rank from $37^{\text {th }}$ for Sun Life to $152^{\text {nd }}$ for CI Financial) had a total of USD 2.5 trillion under management.

${ }^{24}$ Macroprudential policy is therefore defined by reference to an objective (limiting systemic or system-wide financial risk), the scope of analysis (the financial system as a whole and its interactions with the real economy), a set of instruments and their governance (prudential tools and those specifically assigned to macroprudential authorities). See BIS, FSB and IMF (2011).

${ }^{25}$ See Tarullo (2015). 
cycle for the latter, specifically those that address the imbalances associated with the risk-taking channel.

The analysis presented in the previous sections suggests that the role for macroprudential policy to lean against the financial cycle may be very different in SOEs. For modern small, developed countries that are fully integrated with global capital markets, the expected excess returns on government bonds, corporate loans, equities and currencies are largely determined by the asset and liability allocations of global institutions and investors. Macroprudential policies in SOEs are unlikely to affect global risk premia. If both the borrowers and lenders do not attempt to evade the regulations, then the policies will have an effect on the quality and quantity of domestic credit. However, the incentives for households, businesses and financial institutions to take on more risk through other asset classes will be unchanged.

There is some evidence of the reduced effectiveness of macroprudential policies in SOEs. Cerutti, Claessens and Laeven (2015) build a survey-based data set on the usage of macroprudential policies in 119 countries over the period 2000-13. They find that borrower-based policies (such as limits on loan-to-value (LTV) and debt-to-income (DTI) ratios) and financial institution-based policies (such as limits on leverage and dynamic provisioning) appear to be especially effective instruments. However, the evidence of effectiveness is weaker in financially more open economies and those in which financial systems are more sophisticated.

The lower effectiveness of macroprudential tools in SOEs may also result from leakages due to evasion or incomplete coverage of the tools. Aiyar et al. (2014) study macroprudential leakages related to capital regulation by the U.K. Financial Services Authority (FSA) and find that in response to increased regulatory requirements, lending shifted from regulated banks to unregulated foreign branches in the United Kingdom. In a recent survey, Damar and Molico (2016) find that macroprudential measures that target borrowers (e.g., limits on LTV or DTI ratios) appear to be effective in leaning against the housing market imbalances associated with the financial cycle. However, policies that are designed to change lender behaviour are less effective, likely as a result of leakages within the domestic financial system to unregulated lenders or across international borders.

These and other concerns about the effectiveness of the current tools have given rise to policy recommendations to ensure more effective macroprudential policies (e.g., Acharya et al. (2009), BIS, FSB and IMF (2011), Jeanne and Korinek (2013), Aiyar et al. (2014), Tarullo (2015)). One set of recommendations emphasizes policy coordination across borders. For example, the reciprocity provisions under Basel III are an attempt to ensure that domestic regulation is reflected in the balance sheets of international banks operating in the country. Another set emphasizes bolstering the governance arrangements and institutional framework for macroprudential policy to ensure effective surveillance of risk across the domestic regulatory perimeter.

Both sets of recommendations are likely to be important in light of the global cycle. As an example, consider purely domestic regulations that cap the LTV ratio of a mortgage. As the local credit market risk premium will be unchanged, the borrower will have an incentive to increase leverage 
on other assets (or avoid the regulation via third-party financing). Financial intermediaries will also continue their forays into other parts of the riskier asset space.

\section{Limiting the effects of integrated capital markets}

A final set of recommendations is to expand the macroprudential toolkit externally, to potentially include capital controls and currency-based prudential tools (Engel (2015)). If the global financial cycle is leading to financial instability, one method of dealing with it is to avoid the influences of global capital markets partially or altogether.

Capital controls are regulations that apply to cross-border transactions and discriminate based on the residency of the transactor; i.e., they apply only when one of the counterparties is a nonresident. Currency-based measures apply only to transactions in certain currencies (for example, limits on banks' foreign exchange (FX) positions or FX lending). Since the end of Bretton Woods, capital controls have been used largely by emerging and developing economies, and evidence of their effectiveness is available only for these countries. The recent literature has attempted to better measure the usage of these tools (e.g., Pasricha (2012), Pandey et al. (2015), Forbes et al. (2015), Pasricha et al. (2015)) and to design more robust tests for assessing their effectiveness as macroprudential tools.

The evidence is not too supportive for most types of capital controls. Jinjarak et al. (2013) assess the effectiveness of Brazil's tax on inflows, imposed between 2008 and 2011, in stemming capital flows. They use a synthetic control method that allows them to construct counterfactuals (i.e., Brazil with no policy change) for each of these changes. They find no evidence that any tightening of controls was effective in reducing the magnitudes of capital inflows. Pandey et al. (2015) focus on controls on foreign borrowing in India over the period 2004-13, and using a propensity score matching (PSM) methodology that controls for selection bias, do not find evidence that these controls were effective in stemming domestic credit growth. Forbes et al. (2015) also use PSM for a larger sample of 60 countries over the period 2009-11 and find that capital controls did not achieve their stated aims (specifically, influencing exchange rates, capital flows, interest-rate differentials, inflation, equity indices, and different volatilities).

Part of the reason that capital controls have not been found to be effective may be because they are also susceptible to leakages and regulatory arbitrage. There is a conundrum here-while the literature suggests that temporary and targeted controls are more desirable (given the cost of such controls), their targeted nature also makes them more susceptible to arbitrage. For example, Carvalho and Garcia (2008) show that Brazil's tax on short-term inflows were evaded by disguising such flows as foreign direct investment (FDI). Further, Pasricha et al. (2015) show that while tightening of inflow controls was effective in reducing non-resident inflows in the pre-crisis period, they also incentivized residents to reduce their outflows in response, thus nullifying any impact on net capital inflows and the trade-off between exchange rate stability and monetary policy independence.

However, the evidence on currency-based measures appears to be more encouraging. Currencybased tools have most often been used in emerging economies, to limit booms in unhedged 
foreign currency borrowing. Forbes et al. (2015) also found that prudential tools applied to the banking sector (mostly currency-based measures) could reduce some types of financial fragility, i.e., bank leverage and bank credit growth. One of the reasons that currency-based measures may be more effective is that they apply to both residents and non-residents, making them harder to evade.

To summarize, the existence of a global financial cycle means that the risk-taking channel is global as well. Time variation in U.S. policy rates causes large financial intermediaries to change their risk perceptions and to search for yield across the global spectrum of risky assets. Risk premia in SOEs decline. The literature suggests that to diminish the influence of this channel, either globally coordinated macroprudential policies or very broad-based measures in the domestic economy are needed. Alternatively, a country may decide to limit the influence of the global financial cycle via the use of capital controls. The latter are much less desirable policy options.

\section{Conclusions}

New research illustrates the importance of accounting for the impact of the global financial cycle on both conventional and unconventional monetary policies as well as on macroprudential policies in small, open economies. The global financial cycle, driven in part by U.S. monetary policy decisions, affects the asset and liability allocation decisions of financial intermediaries and investors worldwide. Changes in these allocations cause time variation in global risk premia, which affects the domestic monetary policy transmission mechanism in SOEs. It also affects the conduct of macroprudential policies.

While the global financial cycle complicates the implementation of conventional and unconventional monetary policies, it does not imply that these policies are ineffective. The research does point out that the monetary policy transmission mechanism is affected by global risk factors and that these factors may move in the opposite direction to conventional monetary policy moves. This suggests that monetary policy may have to be more aggressive in the future, given the future lower level of the neutral rate. Unconventional policies may become much more conventional.

The buildup of debt during the boom phase of the global financial cycle raises the likelihood of a subsequent financial crisis. New research shows that the central banks can lean against the growth of the debt stock by keeping policy rates higher than warranted by current conditions. This is effective in lowering the likelihood of either a large house price correction or of a financial crisis over the long run. However, these effects are not large enough to overcome the negative consequences for borrowers who face a higher cost of debt. Thus the basic message of Svensson remains: In general, monetary policy should clean, not lean.

However, the costs of risk-taking behaviour induced by accommodative monetary policy should not be discussed in isolation from its benefits. The easing of monetary policy was needed to foster 
macroeconomic stability prior to and during the crisis, and premature removal of monetary stimulus to alleviate risk-taking behaviour could fall short of having a significant impact on the financial imbalance (Bean et al. (2010)), hinder the recovery that it helped generate (Tarullo (2014)), or, under low capital or liquidity levels, even lead to a credit crunch (Jiménez et al. (2012)). In addition, low interest rates may have direct positive effects on financial stability. For example, higher profit margins and lower delinquency and default rates may decrease risk aversion and raise prices of legacy assets or collateral assets, leading to healthier balance sheets (Chodorow-Reich (2014)).

Thus, central banks cannot rely on a combination of conventional and unconventional monetary policies alone to offset the effects of financial crises. Clearly, some form of micro- and macroprudential policies are also required to lower both the likelihood and severity of a crisis. The research surrounding the global financial cycle suggests that macroprudential policies in SOEs need to be coordinated carefully across borders and within the country itself. While capital controls may potentially diminish the impact of global financial cycles, the additional cost that they impose is likely too large. Discussions on potential use of capital controls should also be mindful of the limited evidence of their effectiveness, the absence of adequate cost-benefit analysis in the literature, their potential spillovers (i.e., the potential to divert capital flows to other countries), as well as the limited data available to assess their impact on developed-country capital markets. ${ }^{26}$

${ }^{26}$ See Pasricha et al. (2015), Beirne and Friedrich (2014), Chantapacdepong and Shim (2014) and Forbes et al. (2012) for empirical evidence on spillovers of capital controls. 

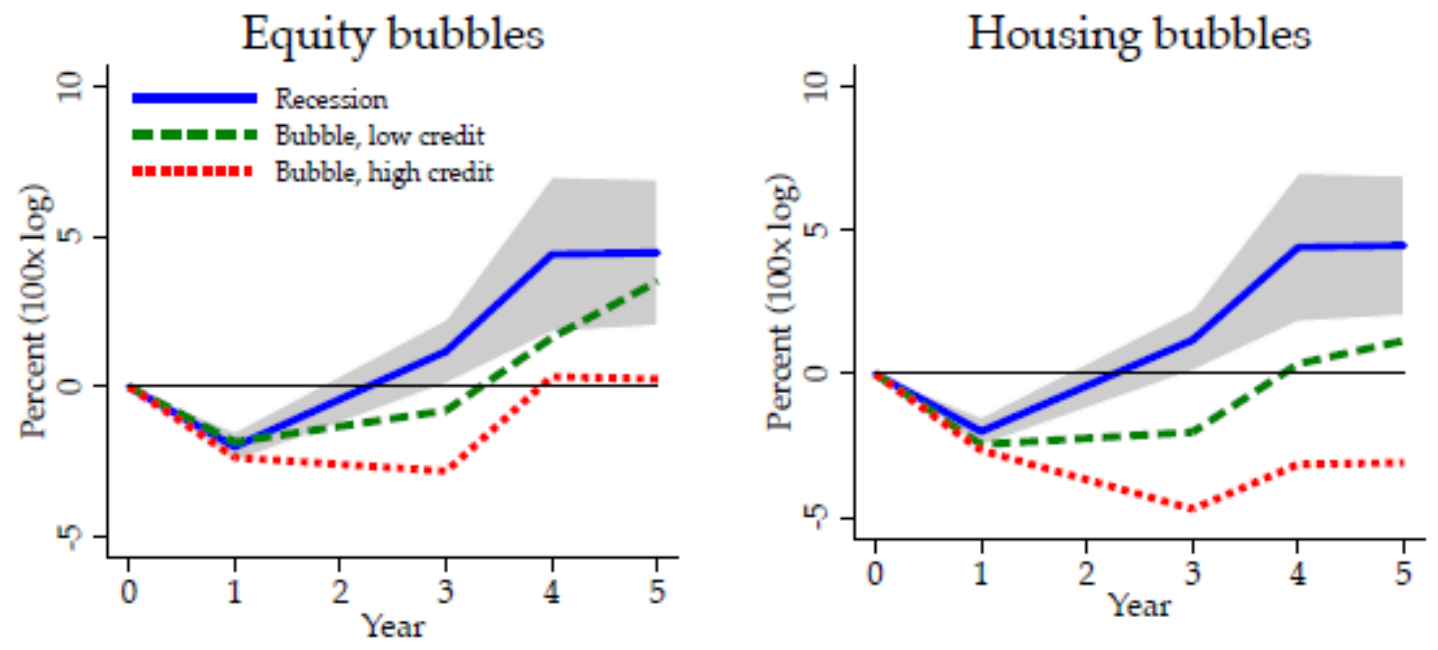

Note: The solid blue line reports the average path of cumulative percentage change in real GDP per capita from the peak of the business cycle (the start of the recession). The grey area represents the $90 \%$ confidence region around the average path. The green dashed line is the sum of the average recession path and the bubble coefficient when credit is below the mean, whereas the dotted red line is the sum of the average recession and the bubble coefficient when credit is high. The figure uses the full sample, 18702012, which excludes both World Wars and a window of five years around them. Source: Figure 7, Jordà, Schularick, and Taylor (2015) 


\section{Chart 2: Expectations component on 10-year government bond yields in Canada and the United States}

Monthly data

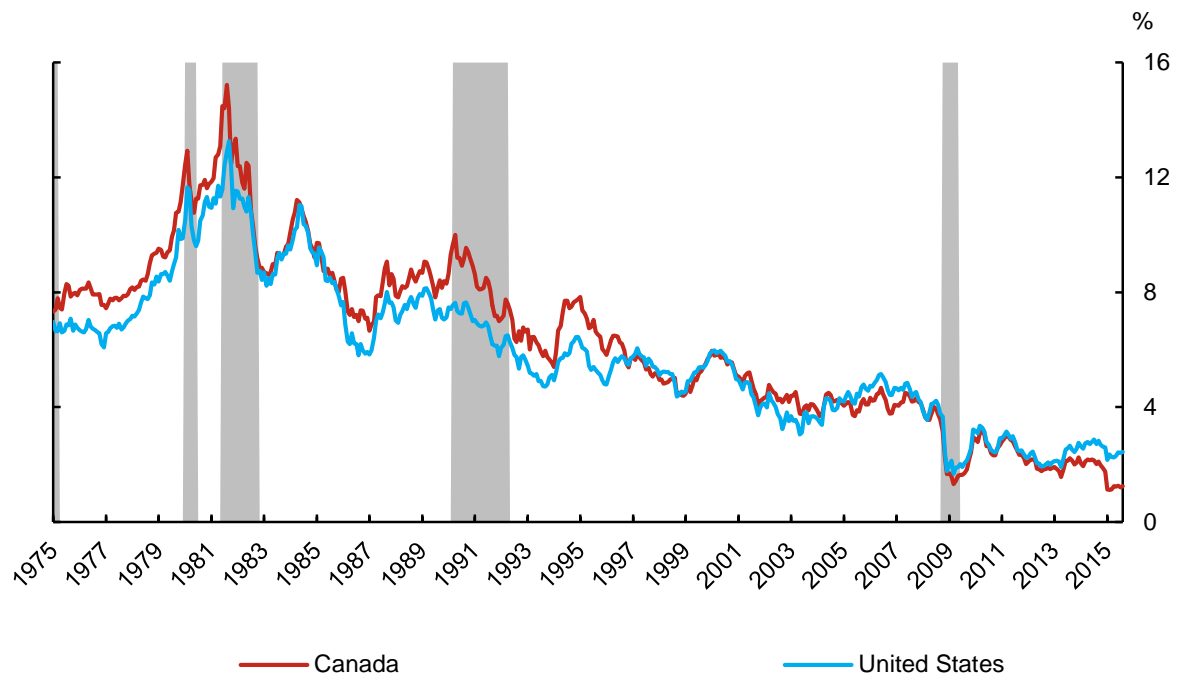

Note: This figure shows the expectations component on a 10-year government bond yield in Canada and the United States estimated with the Bauer and Diez de los Rios (2012) model. The grey bars depict Canadian recessions as per the classification of the CD Howe Institute.

\section{Chart 3: Risk premium on 10-year government bond yields in Canada and the United States}

Monthly data

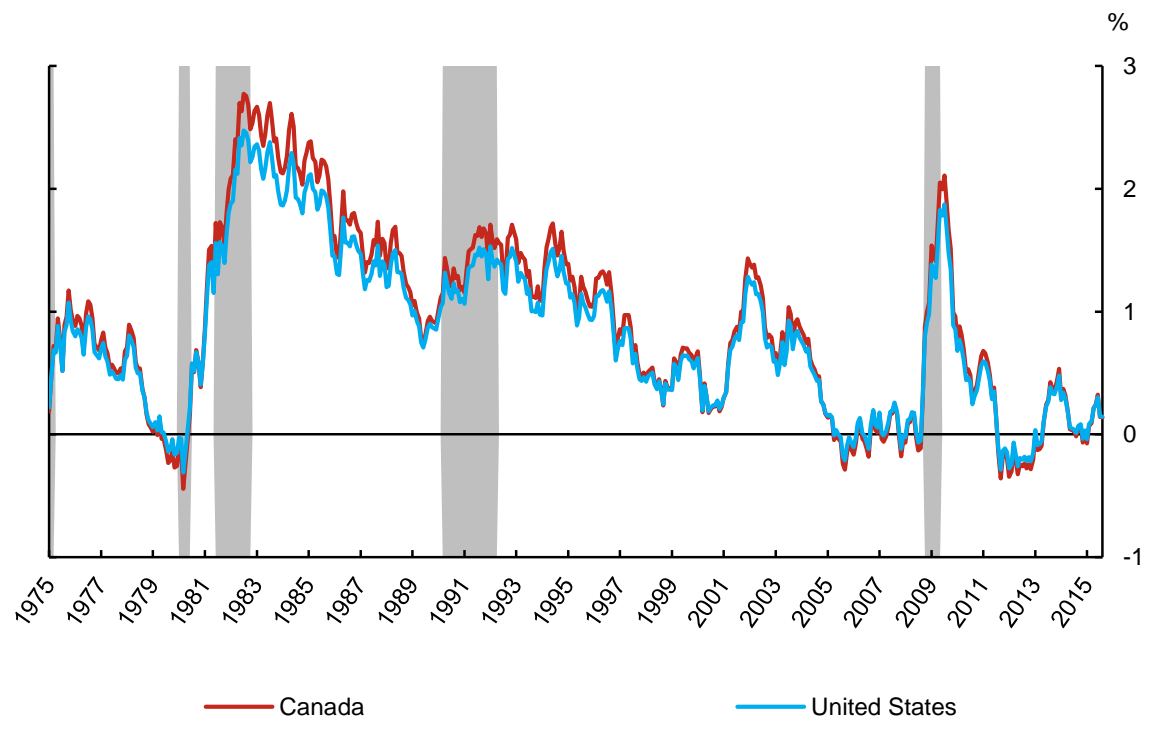

Note: This figure shows the risk premium on a 10-year government bond yield in Canada and the United States estimated with the Bauer and Diez de los Rios (2012) model. The grey bars depict Canadian recessions as per the classification of the CD Howe Institute. 


\section{Chart 4: The Canadian and U.S. conundra: Overnight rates and 10-year government bond yields}

Monthly data

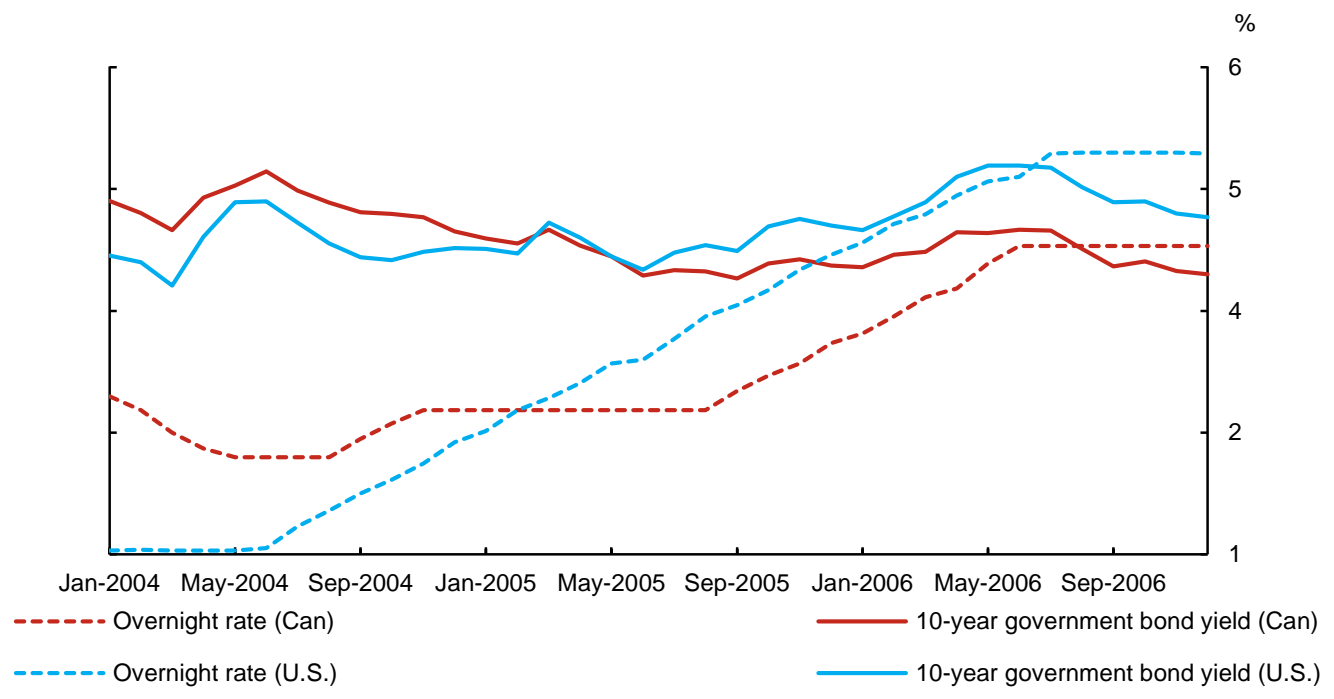

Note: This figure shows the overnight rate in Canada and the United States, as well as their respective 10-year government bond yields from January 2004 to December 2006.

\section{Chart 5: Long-term corporate bond rates over the financial crisis}

Weekly data

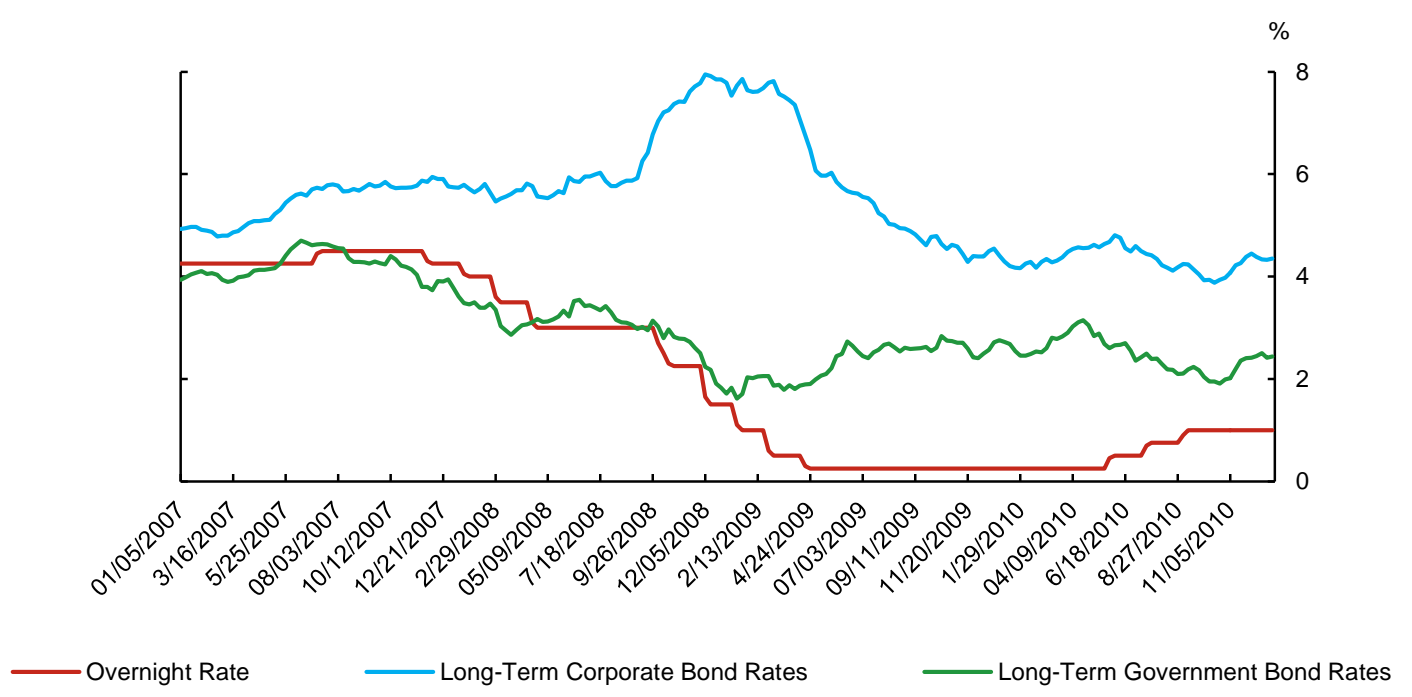

Note: The figure plots the long-term corporate bond rates in Canada along with the overnight and long-term government bond rates during the financial crisis period. While overnight and long-term government bond rates decreased during the financial crisis, risk premium on corporate bonds increased significantly, more than offsetting the decrease in the expectations component. 
Chart 6: $\quad$ Aggregate impulse response functions, from Bauer and Granziera (2016)

Output

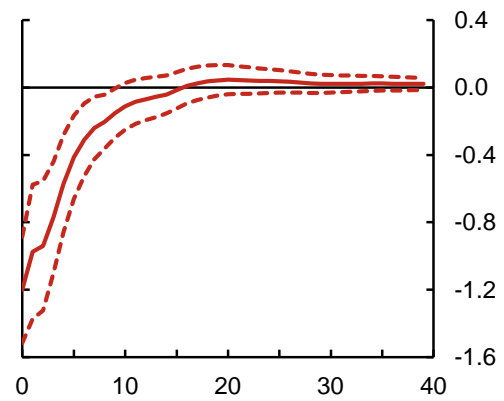

Real House Prices

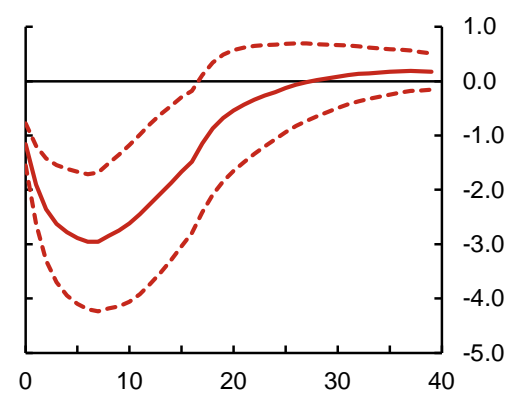

Inflation

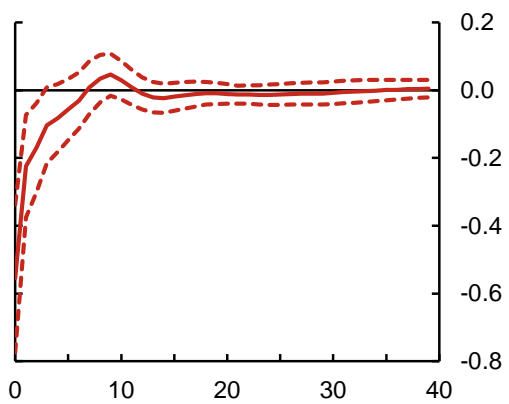

Debt-to-GDP Ratio

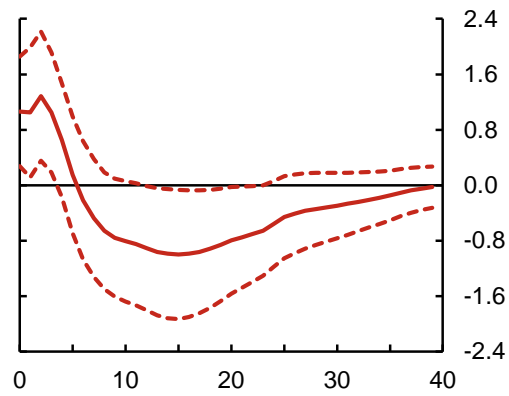

Note: The impulse response functions are for a 100 basis-point increase in the short-term interest rate in each country. A monetary policy shock is identified by sign restrictions: the GDP growth rate, inflation and real house prices are assumed to decline over the first quarter. 


\section{Chart 7: Estimated likelihood of a financial crisis, from Bauer and Granziera (2016)}

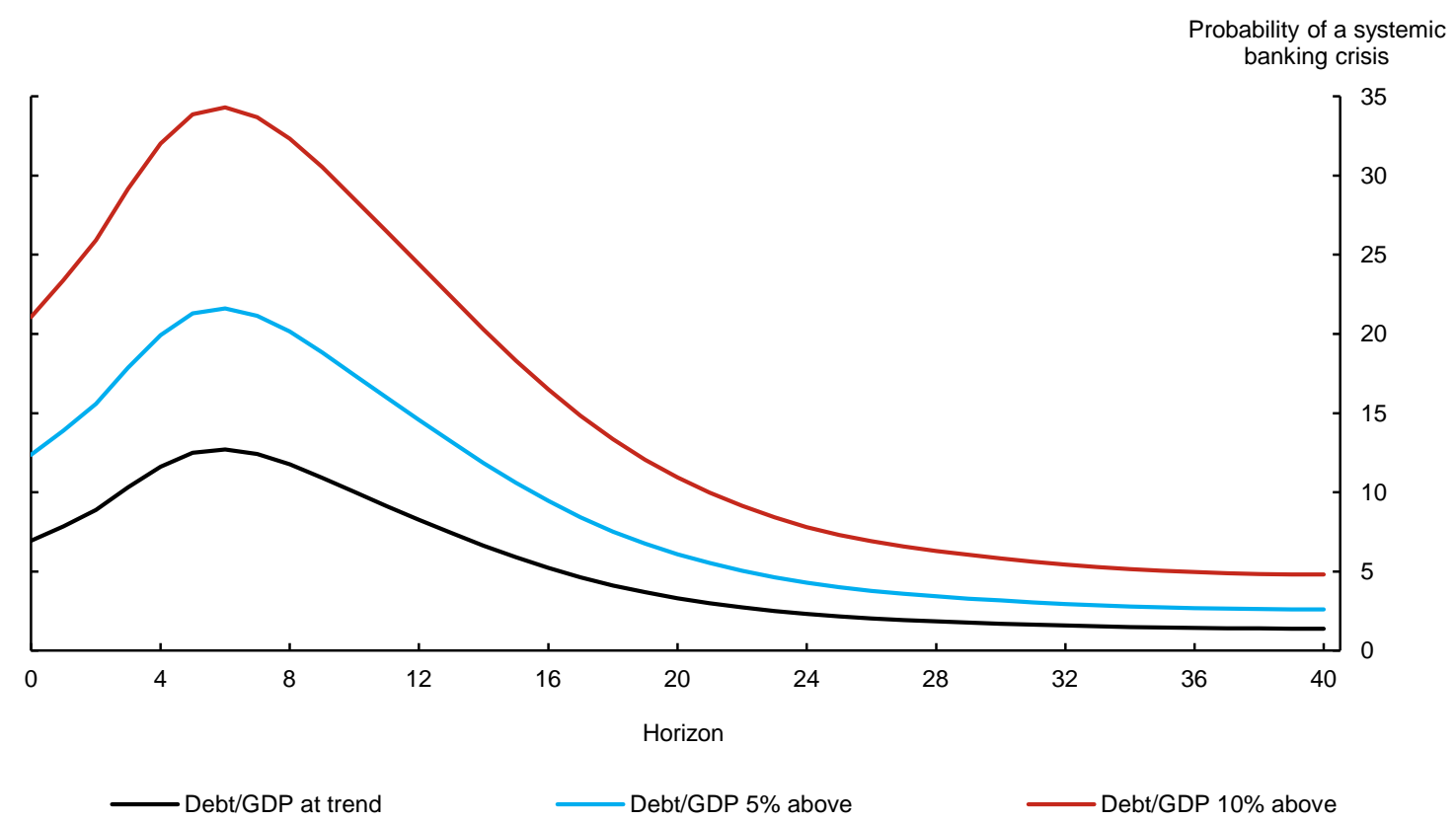

Note: The chart shows the estimated likelihood of a systemic banking crisis starting sometime in the next two years. The likelihood is estimated from the second part of the model in Bauer and Granziera (2016). The likelihood of a banking crisis is driven by the debtto-GDP ratio from the impulse response functions shown in Chart 6 . The likelihood is estimated for three different starting values of the debt-to-GDP ratio: if the ratio is at trend, or if it is at 5 or 10 per cent above trend. 


\section{References}

Acharya, V.V., P. Wachtel and I. Walter. 2009. Restoring Financial Stability: How to Repair a Failed System. edited by Viral V Acharya and Matthew Richardson, John Wiley and Sons.

Adrian, T., P. Colla and H.S. Shin. 2012. "Which Financial Frictions? Parsing the Evidence from the Financial Crisis of 2007-09." NBER Working Paper 18335.

Adrian, T., A. Estrella and H.S. Shin. 2010. "Monetary Cycles, Financial Cycles and the Business Cycle." Federal Reserve Bank of New York Staff Report No. 421.

Adrian, T., E. Moench and H.S. Shin. 2010. "Financial Intermediation, Asset Prices and Macroeconomic Dynamics." Federal Reserve Bank of New York Staff Report No. 422.

Adrian, T., E. Moench and H.S. Shin. 2014. "Dynamic Leverage Asset Pricing." Federal Reserve Bank of New York Staff Report No. 625.

Agrippino, S.M. and H. Rey. 2014. "World Asset Markets and the Global Financial Cycle.” Working Paper London Business School.

Aiyar, S., C. Calomiris and T. Wieladek. 2014. "Identifying Channels of Credit Substitution When Bank Capital Requirements Are Varied." Economic Policy 29 (77): 45-77.

Aizenman, J., M.D. Chinn and H. Ito. 2015. "Monetary Policy Spillovers and the Trilemma in the New Normal: Periphery Country Sensitivity to Core Country Conditions." NBER Working Paper No. 2118.

Allen, F. and D. Gale. 2000. “Bubbles and Crises." Economic Journal 110 (460): 236-255.

Alpanda, S., G. Cateau and C. Meh. 2014. "A Policy Model to Analyze Macroprudential Regulations and Monetary Policy." Bank of Canada Staff Working Paper No. 2014-6.

Alpanda, S. and A. Ueberfeldt. 2016. "Should Monetary Policy Lean Against Housing Market Booms?" Bank of Canada Staff Working Paper No. 2016-19.

Barberis, N. 2013. "Psychology and the Financial Crisis of 2007-2008." In Financial Innovation: Too Much or Too Little? edited by Michael Haliassos. Cambridge: MIT Press.

Baron, M. and W. Xiong. 2014. "Credit Expansion and Neglected Crash Risk." Princeton University Working Paper.

Bauer, G.H. 2014. "International House Price Cycles, Monetary Policy and Risk Premiums." Bank of Canada Staff Working Paper No. 2014-54.

Bauer, G.H. and A. Diez de los Rios. 2012. "An International Dynamic Term Structure Model with Economic Restrictions and Unspanned Risks." Bank of Canada Staff Working Paper No. 2012-5.

Bauer, G.H. and E. Granziera. Forthcoming. "Monetary Policy and Private Debt." Bank of Canada Staff Working Paper.

Bean, C., M. Paustian, A. Penalver and T. Taylor. 2010. "Monetary Policy after the Fall." Paper prepared for the Federal Reserve Bank of Kansas City Annual Conference, Jackson Hole, Wyoming, 28 August.

Bekaert, G., M. Hoerova and M. Lo Duca. 2013. "Risk, Uncertainty, and Monetary Policy." Journal of Monetary Economics, Elsevier 60 (7): 771-778. 
Bekaert, G. and X. Wang. 2010. "Inflation Risk and the Inflation Risk Premium." Economic Policy 25 (64): 755806.

Beirne, J. and C. Friedrich. 2014. "Capital Flows and Macroprudential Policies: A Multilateral Assessment of Effectiveness and Externalities." Bank of Canada Staff Working Paper No 2014-31.

BIS. 2012. "Operationalizing the Selection and Application of Macroprudential Instruments." CGFS Paper No. 48.

BIS, FSB and IMF. 2011. "Macroprudential Policy Tools and Frameworks: Update to G20 Finance Ministers and Central Bank Governors." 14 February.

Borio, C. 2014. "The Financial Cycle and Macroeconomics: What Have We Learnt?" Journal of Banking and Finance 45: 182-198.

Borio, C. and H. Zhu. 2008. "Capital Regulation, Risk-Taking and Monetary Policy: A Missing Link in the Transmission Mechanism?" Journal of Financial Stability 8 (4): 236-251.

Bruno, V. and H.S. Shin. 2015. "Capital Flows and the Risk-Taking Channel of Monetary Policy." Journal of Monetary Economics 71: 119-132.

Büyükkarabacak, B. and N.T. Valev. 2010. "The Role of Household and Business Credit in Banking Crises." Journal of Banking and Finance 34: 1247-1256.

Campbell, J.Y. 1987. "Stock Returns and the Term Structure." Journal of Financial Economics 18 (2): 373-399.

Campbell, J.Y. and Y. Hamao. 1992. "Predictable Stock Returns in the United States and Japan: A Study of Long-Term Capital Market Integration." Journal of Finance, American Finance Association 47 (1): 43-69.

Campbell, J.Y. and R.J. Shiller. 1991. "Yield Spreads and Interest Rate Movements: A Bird's Eye View." The Review of Economic Studies 58 (3): 495-514.

Carvalho, B.S. de M. and M.G.P. Garcia. 2008. "Ineffective Controls on Capital Inflows Under Sophisticated Financial Markets: Brazil in the Nineties." In Financial Markets Volatility and Performance in Emerging Markets, Cambridge, edited by S. Edwards and M. Garcia. Massachusetts: National Bureau of Economic Research.

Cerra, V. and S.C. Saxena. 2008. "Growth Dynamics: The Myth of Economic Recovery." American Economic Review 98 (1): 439-57.

Cerutti, E., S. Claessens and L. Laeven. 2015. "The Use and Effectiveness of Macroprudential Policies: New Evidence." IMF Working Paper No. 15/62.

Chantapacdepong, P. and I. Shim. 2014. "Correlations Across Asia-Pacific Bond Markets and the Impact of Capital Flow Measures." BIS Working Paper No. 472, December.

Chodorow-Reich, G. 2014. "The Employment Effects of Credit Market Disruptions: Firm-level Evidence from the 2008-09 Financial Crisis." Quarterly Journal of Economics 129 (1): 1-59.

Choudhri, E.U. and L. Schembri. 2013. "A Tale of Two Countries and Two Booms, Canada and the United States in the 1920s and the 2000s: The Roles of Monetary and Financial Stability Policies." Carleton University Working Paper.

Christensen, I. and F. Li. 2014 "Predicting Financial Stress Events: A Signal Extraction Approach." Bank of Canada Staff Working Paper No. 2014-37. 
Christensen, J.H. and G.D. Rudebusch. 2012. "The Response of Interest Rates to US and UK Quantitative Easing." The Economic Journal 122 (564): F385-F414.

Claessens, S., M.A. Kose and M.E. Terrones. 2012. "How Do Business and Financial Cycles Interact?" Journal of International Economics, Elsevier 87 (1): 178-190.

Cochrane, J.H. and M. Piazzesi, 2005. “Bond Risk Premia." American Economic Review 95 (1): 138-160.

D'Amico, S. and T.B. King. 2013. "Flow and Stock Effects of Large-Scale Treasury Purchases: Evidence on the Importance of Local Supply." Journal of Financial Economics 108 (2): 425-48.

Dahlhaus, T., K. Hess and A. Reza. 2014. "International Transmission Channels of U.S. Quantitative Easing: Evidence from Canada." Bank of Canada Staff Working Paper No. 2014-43.

Dahlquist, M. and H. Hasseltoft. 2013. "International Bond Risk Premia." Journal of International Economics 90 (1) $17-32$.

Damar, E., C. Meh and Y. Terajima. 2013. "Leverage, Balance-Sheet Size and Wholesale Funding." The Journal of Financial Intermediation 22 (4): 639-662.

- - . 2015. "Effects of Funding Portfolios on the Credit Supply of Canadian Banks." Bank of Canada Staff Working Paper No. 2015-10.

Damar, E. and M. Molico. 2016. "On the Nexus of Monetary Policy and Financial Stability: Effectiveness of Macroprudential Tools in Building Resilience and Mitigating Financial Imbalances." Bank of Canada Staff Discussion Paper No. 2016-11.

Dell'Ariccia, G., D. Igan, L. Laeven and H. Tong. 2012. "Policies for Macrofinancial Stability: How to Deal with Credit Booms." IMF Staff Discussion Note 12-06.

Demirgüç-Kunt, A. and E. Detragiache. 1997. "The Determinants of Banking Crises in Developing and Developed Countries." IMF Staff Papers 45: 81-109.

Drehmann, M., C. Borio and K. Tsatsaronis. 2011. "Anchoring Countercyclical Capital Buffers: The Role of Credit Aggregates." International Journal of Central Banking 7 (4): 189-240.

- - . 2012. "Characterizing the Financial Cycle: Don't Lose Sight of the Medium Term!" BIS Working Paper No 380 .

Driessen, J., B. Melenberg and T. Nijman. 2003. "Common Factors in International Bond Returns." Journal of International Money and Finance, Elsevier 22 (5): 629-656.

Engel, C. 2015. “Macroprudential Policy Under High Capital Mobility.” NBER working paper 20951.

Fama, E.F. and R.R. Bliss. 1987. "The Information in Long-Maturity Forward Rates." The American Economic Review 77 (4): 680-692.

Forbes, K., M. Fratzscher, T. Kostka and R. Straub. 2012. "Bubble They Neighbor: Portfolio Effects and Externalities." ECB Working Paper No. 1456, August.

Forbes, K., M. Fratzscher and R. Straub. 2015. "Capital-Flow Management Measures: What Are They Good For?" Journal of International Economics, Elsevier 96 (S1): S76-S97.

Gagnon, J., M. Raskin, J. Remache and B. Sack. 2011. "The Financial Market Effects of the Federal Reserve's Large-Scale Asset Purchases." International Journal of Central Banking 7 (1): 3-43. 
Gertler, M. and P. Karadi. 2015. "Monetary Policy Surprises, Credit Costs, and Economic Activity." American Economic Journal: Macroeconomics 7 (1): 44-76.

Gilchrist, S. and E. Zakrajsek. 2012. "Credit Spreads and Business Cycle Fluctuations." American Economic Review 102 (4): 1692-1720.

Hanson, S.G. and J.C. Stein. 2015. "Monetary Policy and Long-Term Real Rates." Journal of Financial Economics 115 (3): 429-448.

Harvey, C.R., B. Solnik and G. Zhou. 2002. "What Determines Expected International Asset Returns?" Annals of Economics and Finance, Society for AEF 3 (2): 249-298.

Hellerstein, R. 2011. “Global Bond Risk Premiums.” Federal Reserve Bank of New York Staff Report 499.

Jeanne, O. and A. Korinek. 2013. "Macroprudential Regulation Versus Mopping Up After the Crash." NBER Working Paper 18675.

Jiménez, G., S. Ongena, J.L. Peydró, and J. Saurina. 2012. "Credit Supply and Monetary Policy: Identifying the Bank Balance-Sheet Channel with Loan Applications." American Economic Review 102 (5): 2301-2326.

- - . 2014. "Hazardous Times for Monetary Policy: What Do Twenty-Three Million Bank Loans Say About the Effects of Monetary Policy on Credit Risk Taking?" Econometrica 82 (2): 463-505.

Jinjarak, Y., I. Noy and H. Zheng. 2013. "Capital Controls in Brazil - Stemming a Tide with a Signal?" Journal of Banking and Finance 37 (8): 2938-2952.

Jordà, Ò., M. Schularick and A.M. Taylor. 2011. "Financial Crises, Credit Booms, and External Imbalances: 140 Years of Lessons." IMF Economic Review 59 (2): 340-78.

- - . 2014. "The Great Mortgaging: Housing Finance, Crises, and Business Cycles." NBER Working Paper 20501.

---. 2015. “Leveraged Bubbles." NBER Working Paper 21486.

Kapetanios, G., H. Mumtaz, I. Stevens and K. Theodoridis. 2012. "Assessing the Economy-wide Effects of Quantitative Easing." The Economic Journal 122 (564): F316-F347.

Klein, M. and J. Shambaugh. 2015. "Rounding the Corners of the Policy Trilemma: Sources of Monetary Policy Autonomy." American Economic Journal: Macroeconomics 7 (4): 33-66.

Krishnamurthy, A. and T. Muir. 2015. "Credit Spreads and the Severity of Financial Crises." Stanford GSB Working Paper.

Krishnamurthy, A. and A. Vissing-Jorgensen. 2011. "The Effects of Quantitative Easing on Interest Rates: Channels and Implications for Policy." Brookings Papers on Economic Activity (Fall): 215-87.

Lewis, K. 2011. "Global Asset Pricing." Annual Review of Financial Economics 3: 435-466.

Longstaff, F., J. Pan, L. Pedersen and K. Singleton. 2011. "How Sovereign is Sovereign Credit Risk?" American Economic Journal: Macroeconomics 3 (2): 75-103.

Mendes, R. 2014. "The Neutral Rate of Interest in Canada." Bank of Canada Staff Discussion Paper No. 20145.

Mian, A. and A. Sufi. 2015. "Household Debt and Defaults from 2000 to 2010: Facts from Credit Bureau Data." NBER Working Paper 21203. 
Neely, C. J. 2015. "Unconventional Monetary Policy Had Large International Effects." Journal of Banking and Finance 52: 101-111

P\&I Towers Watson. 2014. "The P\&I Towers Watson World 500: World's Largest Managers." Annual Report.

Paligorova, T. and J. Santos. 2012. "When Is It Less Costly for Risky Firms to Borrow? Evidence from the Bank Risk-Taking Channel of Monetary Policy." Bank of Canada Staff Working Paper No. 2012-10.

Paligorova, T. and J. Sierra. 2012. "Monetary Policy and the Risk-Taking Channel: Insights from the Lending Behaviour of Banks." Bank of Canada Review (Autumn): 23-30.

Pandey, R., G.K. Pasricha, I. Patnaik and A. Shah. 2015. "Motivations for Capital Controls and Their Effectiveness." Bank of Canada Staff Working Paper No. 2015-5.

Pasricha, G.K. 2012. "Recent Trends in Measures to Manage Capital Flows in Emerging Economies." North American Journal of Economics and Finance 23 (3): 286-309.

Pasricha, G.K., M. Falagiarda, M. Bijsterbosch and J. Aizenman. 2015. "Domestic and Multilateral Effects of Capital Controls in Emerging Markets.” NBER Working Paper No. 20822.

Pasricha, G.K., T. Roberts, I. Christensen and B. Howell. 2013 "Assessing Financial System Vulnerabilities: An Early Warning Approach." Bank of Canada Review (Autumn): 10-19.

Passari, E. and H. Rey. 2015. "Financial Flows and the International Monetary System." The Economic Journal, 0 (584): 675-698.

Perignon, C., D.R. Smith and C. Villa. 2007. "Why Common Factors in International Bond Returns Are Not so Common." Journal of International Money and Finance, Elsevier 26 (2): 284-304.

Poloz, S. 2015. "Prudent Preparation: the Evolution of Unconventional Monetary Policies." Remarks to the Empire Club of Canada, Toronto, Ontario, 8 December.

Rangvid, J., M. Schmeling and A. Schrimpf. 2014. "Dividend Predictability Around the World." Journal of Financial and Quantitative Analysis 49 (5-6): 1255-1277.

Reinhart, C.M. and K.S. Rogoff. 2009. "This Time is Different: Eight Centuries of Financial Folly." Princeton Press.

- - 2014. "Recovery from Financial Crises: Evidence from 100 Episodes." American Economic Review 104 (5): 50-55.

Rey, H. 2014. "The International Credit Channel and Monetary Autonomy." IMF Mundell-Fleming Lecture. Washington, DC, November.

- - . 2015. "Dilemma not Trilemma: The Global Financial Cycle and Monetary Policy Independence." NBER Working Paper No. 21162.

Reza, A., E. Santor and L. Suchanek. 2015. "Quantitative Easing as a Policy Tool Under the Effective Lower Bound." Bank of Canada Staff Working Paper No. 2015-14.

Rogers, J., C. Scotti and J. Wright. 2015. "Unconventional Monetary Policy and International Risk Premia." Federal Reserve Board Working Paper No. 2016-1172.

Saporta, V. 2009. "The Role of Macroprudential Policy." Bank of England Discussion Paper (November). 
Schularick, M. and A. Taylor. 2012. "Credit Booms Gone Bust: Monetary Policy, Leverage Cycles, and Financial Crises, 1870-2008." American Economic Review 102: 1029-1061.

Shin, H.S. 2015. "Global Liquidity and Monetary Policy Transmission." Panel Remarks at the European Economic Association's Annual Congress, Mannheim, Germany, August.

Svensson, L. 2014. "Inflation Targeting and Leaning against the Wind." International Journal of Central Banking 10 (2): 103-114, June.

- - . 2015. "A Simple Cost-Benefit Analysis of Using Monetary Policy for Financial Stability Purposes." In Rethinking Macro Policy III: Progress or Confusion, edited by O.J. Blanchard, R. Rajan, K.S. Rogoff and L.H. Summers. Cambridge: MIT Press.

Tarullo, D. 2014. "Monetary Policy and Financial Stability." Remarks at the 30th Annual National Association for Business Economics Economic Policy Conference, Arlington, Virginia, 25 February.

- - . 2015. "Advancing Macroprudential Policy Objectives." Remarks at the Office of Financial Research and Financial Stability Oversight Council's 4th Annual Conference on Evaluating Macroprudential Tools: Complementarities and Conflicts, Arlington, Virginia, 30 January. 